\title{
Overview of The Implementation of Occupational Health and Safety (OHS) in Preventing The Transmission of Covid 19 in PT PKUA Bogor West Java 2021
}

\author{
Wiwin Listyowati \\ Faculty of Public Health, Muhammadiyah University of Jakarta \\ K.H. Ahmad Dahlan St, Cireundeu Ciputat, South Jakarta, 15419 \\ E-mail: wiwinistio29@gmail.com
}

\begin{abstract}
Since the pandemic that began in 2020, the industry in Indonesia has experienced enormous obstacles and has an impact on the industrial workers themselves, the Covid 19 infection rate in workers has reached 2 percent of the total number of infections in Indonesia and industrial areas. The purpose of this study was to see an overview of the application of occupational health and safety (OHS) in preventing the transmission of covid 19 at PT PKUA Bogor, West Java. The method used in this research is descriptive qualitative with data collection techniques through observation, literature study with secondary data, and interviews with employees of PT PKUA. The results obtained from this study are based on data from the company's OHS division and interviews with the Factory Manager, it is known that the number of workers infected with Covid 19 as of April 2021 was 8 people and those who were not infected were 119 people out of a total of 127 employees. The transmission that occurred within the company was not significant and there was no spread within the factory because the workers who were infected while on duty were out of town and did not form a factory cluster. In the company, from the HSE division report, it was found that employees were infected while on duty from out of town and came into contact with many people on their way to and from them. This research concludes that PT PKUA has done quite well to prevent the occurrence of factory clusters, the preventive measures taken have been in favor of the safety and health of industrial workers, especially in PT PKUA.
\end{abstract}

Keywords: K3, Prevention, Covid 19 


\section{INTRODUCTION}

Since 2020 the Covid 19 virus pandemic in Indonesia has not decreased until now, this pandemic has made industry players experience changes in industrial governance, even to changes in demand for goods and services. This of course has an impact on workers in these industries.

The industrial sector in Indonesia is experiencing quite hard obstacles during the COVID-19 pandemic. As a sector that contributes $20 \%$ of the national GDP, this certainly affects the movement of Indonesia's economic growth throughout 2020. In the current Covid-19 pandemic, the economy in Indonesia must continue to run by prioritizing preventive measures. Guidelines for the Prevention and Control of Covid-19 in the Office and Industrial Workplaces have been issued by the Indonesian Ministry of Health by issuing the Decree of the Minister of Health number HK.01.07/MENKES 1328/2020 to support business continuity in a pandemic situation, by keeping workers from being exposed covid 19 virus and minimize the incidence of covid 19 infection in workers, because the business world and the working community have a major contribution in breaking the chain of transmission due to a large number of the working population and also a large number of mobility, as well as population interaction generally due to work activities, it is required to apply health protocols in such a way as to avoid this Covid 19 pandemic. ${ }^{1}$

In the world of OHS (Occupational Health and Safety), there is already a method for controlling risk in the workplace, known as the Hierarchy of risk control for physical, mechanical, chemical, and biological risks, for example, Covid 19 as it is today. Hence the importance of the role of $\mathrm{K} 3$ in the control and prevention of the risk of contagion Covid 19th in the industry, especially manufacturing to prevent the occurrence of cluster Covid 19 at the factory or company in order not to disturb the smooth nets, production, and business as well as protect workers from the dangers of contagion Covid 19. Hierarchy risk control in the case of covid 19 based on the order of K3 control such as :
a. Elimination
b. Substitution
c. Engineering / Design Control
d. Administrative Control
e. Personal Protective Equipment (PPE)

Elimination in the risk control hierarchy is a step that has the highest level of effectiveness, reliability, and protection among other controls. In the workplace, elimination is defined as eliminating a source of danger, then at further right to substitute that by replacing or adding tools or machines and materials to reduce the risks posed by exposure. The third hierarchy is engineering control where the concept of modification or design of tools or machines for a safer and more comfortable workplace is applied. The three controls are carried out at the workplace or work to make 
it safer by reducing hazards. Administrative Control is a control hierarchy at the next stage, namely by applying procedures, rules, training, work duration, danger signs, signs, posters, labels, and other administrative matters. The last control is the use of personal protective equipment (PPE) for workers. These two measures can be grouped focusing on safe labor by reducing exposure. ${ }^{2}$

In Indonesia, positive cases of Covid 19 in industrial workers account for 2 percent of the total cases, the data recorded by the Ministry of Industry noted that of the total positive cases of Covid 19 currently, around 2 percent are factory employees. ${ }^{3}$

In West Java, the highest positive cases for industrial workers were in Karawang Regency, which experienced a spike in Covid 19 cases after an industrial cluster occurred. More than 3,000 employees from 270 industrial companies have been exposed to Covid $19 .{ }^{4}$

For the Bogor district itself, during the 18th PSBB period, the number of positive Covid 19 cases reached 10,441 cases, with details of 92 cases of death, 9,669 cases recovered, and 674 cases of Covid 19 still active and $2 \%$ of them were in the industrial cluster. ${ }^{5}$

PT PKUA through HRD and the HSE Division continues to take preventive measures to minimize transmission within the company by routinely conducting antigen tests to all employees once a month, checking body temperature by the HSE Division before entering the factory area, preparing sanitation equipment in the factory area, requiring the use of masks, disinfection of prayer rooms and work areas, put up warning banners and promotions of prevention in all areas of the factory, as well as requiring workers who have just returned from out of town to carry out antigen tests before and after carrying out assignments outside the city. Based on data obtained from the HSE Division as of April 2021, 8 employees were positively infected with Covid 19. All infected employees were asymptomatic so they were required to self-isolate at home for 14 days and then the HSE Division carried out investigations and tracing to employees who had contact with the asymptomatic patient is to conduct an antigen test as a form of prevention so that transmission can be detected early and can prepare countermeasures. The HSE Division also carries out the Covid 19 risk control hierarchy in the factory area by adjusting the distance in the work area, arranging rest and prayer times in shifts so that there are no crowds, preparing hand washing areas near the work area, preparing spare masks.

This study aims to look at the picture Implementation Of Health And Safety (OHS) In The Prevention Of Transmission Covid 19 at PKUA Bogor West Java as well as providing advice on doing preventive there was his new cluster transmission Covid 19 in PT PKUA Bogor West Java.

\section{METHODS}

This research design uses a qualitative descriptive method with data collection techniques through observation, interviews, and literature studies with secondary data obtained from the HSE Division of PT PKUA Bogor West Jawa, publication of company policies related to covid 19 
prevention procedures in the manufacturing sector, and regulations related to This research also examines journals related to the prevention of covid 19 in the manufacturing sector.

\section{RESULTS AND DISCUSSIONS}

From the results of observations made at PT PKUA regarding the implementation of K3 in the prevention and control of Covid 19 in the factory area, it can be seen that the management has made various efforts to prevent covid 19 in the work area, among others; 1 . Formed a Covid-19 Handling Team at the PT PKUA factory with personnel consisting of the Leader (Director), HRD, HSE Division, and doctors from the company's partner clinics which were strengthened by a Decree from the PKUA Director. 2. The Director's policy in implementing procedures for workers is to report any suspected cases of Covid 19 (symptoms of fever or cough/runny nose/throat pain/shortness of breath) to be tested for antigen first followed by PCR at the hospital appointed by the company. 3 . Setting up a work from the home system (work from home / WFH ) for non-production parts. 4. When entering the factory area, temperature measurements are taken at the entrance /security post using a thermogenic, checking the correct mask, and before entering work apply the Covid 19 Risk Self Assessment with the Google form to ensure workers who will enter work are not exposed to or infected with Covid 19. 5. Mandatory hand washing for 20 seconds as often as possible, at the handwashing areas that have been prepared in the factory area as many as 15 handwashing points. 6 . Provide a spare mask if the mask used is dirty or wet. 7. Meetings working time so that not too long (over time) so that employees do not have sufficient time to rest which can cause a decrease in the immune system/immunity. 8. Put up posters and appeals to maintain personal hygiene and discipline using masks and advice not to crowd. 9. Safety Briefing is carried out in sections so that there are not too many crowds. 10. Provide additional vitamins to all employees to maintain their immune system. 11. Set the distance when working so as not to be too close to other employees. 12. Arrange breaks, prayers, and lunch in turns so that there are no crowds in the factory area. And must bring prayer equipment from their respective homes.13.Install additional exhaust so that the circulation of the room is maintained properly. 14. Exercise and sunbathe for 15 minutes before starting work. 15. If there are employees who have symptoms of Covid 19, they will be referred to a partner clinic for an antigen test, then referred to a hospital appointed by the company for a PCR test and health check-up. 16. If the employee is positive, it will be continued with the recommended action from the doctor, whether to be treated or self-isolated. 17. The HSE and HRD teams traced employees who had contact with the patient and were immediately tested for antigen and then advised to self-isolate for 14 days. 18. For employees on duty out of town, before and after returning, they are required to do an antigen test before entering work as usual. 19. Carry out continuous appeals and promotions regarding the prevention of Covid 19 in the factory area.

Based on the results of interviews with the production manager, 8 people were infected with Covid 19 because after serving from outside the city, and they immediately carried out self-isolation 
after going through the inspection stage. As the production manager said, "... until April 2021 there are about eight people who are positive and immediately ironman after the test and check, the positive ones are just out of town assignments, Alhamdulillah now they have recovered and are back to work as usual...". So far, no new clusters have been formed in the factory. Data on employees who are positive for COVID can be seen in the graph below:

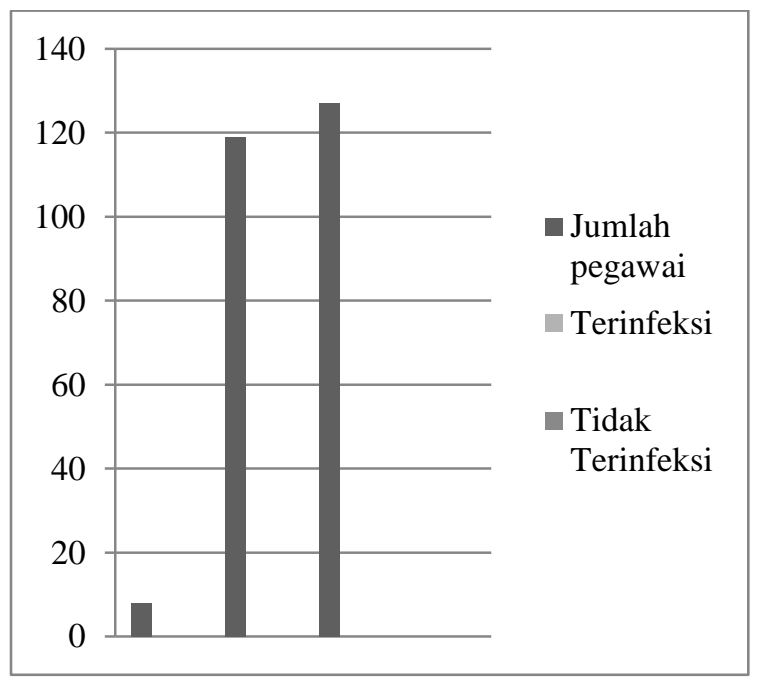

Graph 1. Data of workers infected with Covid 19 and not infected with Covid 19 as of April 2021

Source: Secondary data of PT PKUA 2021 HSE Division

From the above chart, we can see that the employees of PT PKUA who have been infected in Covid 19 per April 2021 as many as 8 people and were not infected as many as 119 people of the total employees as many as 127 people.

From the graph above, it can be seen that the transmission that occurred was insignificant and there was no spread within the factory because all of them were infected while on duty outside the city and did not form a factory cluster, it was based on the prevention efforts that have been carried out above which have been implemented effectively. and discipline in the company. Employees can be infected while on duty from outside the city because they must be in contact with many people when traveling to and from which cannot be avoided, especially if the employee's condition is tired and his immunity is not good. This is following the guidelines in the workplace for the prevention and control of Covid 19 which was released by that one of the programs that must be carried out for workers is the Wellness Program where diet and fatigue, as well as work stress, make the immune system decrease and it is easy to get infected with the virus, especially Covid $19 .{ }^{6}$

When viewed in terms of the control that has been carried out by PT PKUA, it has been carried out quite well such as administrative controls including forming a Covid-19 Handling Team at the PT PKUA factory with personnel consisting of the Leader (Director), HRD, HSE Division and doctors from partner clinics. Companies that are strengthened by a Decree from the Director of 
PKUA. The Director's policy in implementing procedures for workers is to report any suspected cases of Covid-19 (symptoms of fever or cough/runny nose/throat pain/shortness of breath) to be tested for antigen first followed by PCR at the hospital appointed by the company. The arrangement of the work from the home system (work from home / WFH ) for the non-production section is considered to be good enough to prevent transmission within the factory following the Hierarchy of Control in the Workplace in the Covid 19 Case from the OHS Point of view, which was started by the Chairperson of the PPNI North Kalimantan DPW that administrative control by making policies, rules or SOPs related to the anticipation of Covid 19 and providing education/health talk to the public and workers through posters or like writing that is part of the administration. ${ }^{2}$

Of the various kinds of control in at an s that have been carried out by PT PKUA, The flavor is quite good and following the hierarchy of controlling an OHS workplaces such as Elimination to perform self-isolation. Substitutions such as changing attendance in a google form without a fingerprint and meeting in a virtual way without face to face. Engineering Control prepares sanitation media such as hand washing and disinfectant liquid and adds a suction fan or exhaust fan so that circulation remains good. the use of Personal Protection Equipment is the last step, namely the use of a good and correct mask. ${ }^{7}$

\section{CONCLUSION AND SUGGESTIONS}

Based on the discussion above, the actions that have been taken by PT PKUA in preventing the transmission of Covid 19 infection in the company area are quite good, supported by the Management, HSE, and HRD in implementing regulations as well as risk mitigation and handling follow up to employees infected with Covid 19. The Covid 19 control team at PT PKUA was quite effective in preventing the occurrence of a factory cluster at PT PKUA Bogor, West Java.

\section{REFERENCES}

1. Ministry of Industry Public Relations. 2020. The Ministry of Industry Ensures that Industrial Activities and Covid-19 Prevention Protocols Can Go Together.

2. https://kemenperin.go.id/article/21679/Kemenperin-Pastikan-Activity-Industri-dan-ProtocolPentahanan-Covid-19-Can-Berjalan-Beriran (accessed on May 2, 2021. 23:15 WIB).

3. Rahman, Abdul. 2020. Hierarchy of Workplace Control in Covid-19 Cases from the K3 Angle.

4. https://presisi.co/read/2020/04/02/735/hierarchy-of-control-place-work-dalam-case-covid-19dari-angle-k3 (accessed May 6, 2021. 21:42 WIB).

5. Nurcahya. Ipak, Ayu. 2020. Minister of Industry: Positive Covid-19 from the Factory Only 2 Percent. https://ekonomi.bisnis.com/read/20200920/257/1294115/menperin-positive-covid-19dari-pabrik-only-2-percent (accessed on May 8, 202. 22:10 WIB) 
6. Kusuma, Nila. 2021. Worryingly, 3,000 Factory Employees in Karawang are Exposed to COVID-19 . https://region.sindonews.com/read/297118/701/ worrying -3000-karyawan-pabrikdi-karawang-terpapar-covid-19-1610341285 (accessed May 8, 2021. 22:47)

7. Antara/JPNN . 2021. Hamdalah, COVID-19 Cases in Bogor Regency Begin to Slope.

8. https://www.jpnn.com/news/hamdalah-case-covid-19-di-kabupaten-bogor-mulaimelandai ( accessed on May 8, 2021. 23:01 WIB )

9. ILO. 2020. GUIDELINES in the Workplace COVID-19 Prevention and Control.

10. https://www.ilo.org/wcmsp5/groups/public/---asia/---ro-bangkok/---ilojakarta/documents/publication/wcms_769266.pdf ( accessed May 10, 2021. 17.25 WIB)

11. ILO. 2020. Return to work safely and healthily during the COVID-19 pandemic. https://www.ilo.org/wcmp5/groups/public/---asia/---ro-bangkok/---ilo-jakarta /documents/publication/wcms_746742.pdf (accessed May 9, 2021. 22:58 WIB)

12. HSE division. 2021. Monthly HSE PKUA Safety Patrol Report. PT PKUA. Bogor West Java

13. HSE division. 2021. PT PKUA's Covid 19 handling procedure. PT PKUA. Bogor West Java 
Volume I Tahun 2021

November 2021
E-ISSN: 2808-5361

http://e-journal.fkmumj.ac.id/
Proceeding The First Muhammadiyah InternasionalPublic Health and Medicine Conference 